\title{
Climate Change, Regional Water Balance and Land Use Policy, in the Watershed of Lake Kinneret (Israel)
}

\author{
Moshe Gophen, Moshe Meron, Valerie Levin-Orlov, Yosef Tsipris, Mordechay Peres \\ MIGAL-Scientific Research Institute, Kiryat Shmona, Israel \\ Email: Gophen@Migal.org.il
}

How to cite this paper: Gophen, M., Meron, M., Levin-Orlov, V., Tsipris, Y. and Peres, M. (2020) Climate Change, Regional Water Balance and Land Use Policy, in the Watershed of Lake Kinneret (Israel). Open Journal of Ecology, 10, 200-224.

https://doi.org/10.4236/oje.2020.104014

Received: March 12, 2020

Accepted: April 25, 2020

Published: April 28, 2020

Copyright () 2020 by author(s) and Scientific Research Publishing Inc. This work is licensed under the Creative Commons Attribution International License (CC BY 4.0).

http://creativecommons.org/licenses/by/4.0/

\begin{abstract}
Long term data record (1944-2018) of climatological conditions in the Lake Kinneret and its watershed ecosystems was statistically evaluated and the impact of Anthropogenic operations was included as well. Precipitation input source is obviously uncontrolled natural component whilst the other three regional water outflows pathways are under anthropogenic control: Evapo-transpiration (ET), Runoff and underground flows. Indications for climate change expressed as air warming with consequences on regional (watershed and the lake) water resources and consumption capacities policy in the drainage basin and in the Lake are discussed. The decline of air temperature from 1940 to 1970s is probably due to a change in the Albedo effect. After the decline air temperature was twisted towards elevation. Climate change caused a decline in rainfall, followed by a reduction of Jordan and other river discharges and underground flows, accompanied by a decline of WL. With respect to climate change, water allocation for agricultural consumption was shrunk.
\end{abstract}

\section{Keywords}

Watershed, Climate Change, Regional Water Balance, Kinneret Water Level

\section{Introduction}

A paper was published by [1] [2] in which the author claimed that WL decline in Lake Kinneret (Israel) is mostly due to the allocation of too much water for agricultural irrigation in the upper Jordan watershed. This largely unsubstantiated statement ignores much available data on the subject and should be classified as scientifically sloppy and irresponsible. Consequently, the present paper is 
aimed at a public significance rebuttal through the incorporation of larger and more useful information. Moreover, during a very long time (1970-2020) there was a fairly agreeable water allocation partitioning between human consumption and agricultural utilization in the Kinneret watershed which enabled reasonable coexisted comprehensive accomplishment of the human, nature and water supply demands. For example: the most common winter increase in the Kinneret water level was 1.65 meters. Nevertheless, during temporal droughts of 1960 , $1961,1973,1979,1998,2000,2001,2014-2018$ (13 years, out of recorded 83, $16 \%)$, the annual water inputs through the Jordan River was below $300 \mathrm{mcm}\left(10^{6}\right.$ $\mathrm{m}^{3}$ ) and consequently annual Lake Water level increase was less than 1.0 meter and water allocation to agriculture was severely restricted as well. Moreover, during the winters of 2015/16,2016/17, water level increased by 0.61 and $0.87 \mathrm{~m}$ respectively. Unpredictably during the following winters of 2018/19 and 2019/20 (through March) and unpredictable rain measure was followed by WL increase of 3.41 and 3.1. Agriculture demands were fully implemented then.

Regional water balance includes four major components: Rainfall, Evapo-transpiration (ET), underground capacity and runoff. Precipitation and ET are strongly affected by climate conditions. Evapo-transpiration by climate conditions, anthropogenic implementation of Land Use-Land Cover. ET, rainfall and soil features determine the runoff and the underground capacity regimes. The far and close history of vegetation cover within the northern part of the Kinneret drainage basin is widely known. Three major events have been the dominant factors that enhanced changes of the vegetation cover: 1) the drainage of the old Hula Valley and adjacent swampy area (1950-1957); 2) the prominent migration of Jewish settlers into the region accompanied by the establishment of settlements (Kibbutzim) and agricultural developments, which was significantly intensified from the late 1930s; 3) the construction of the National Water Carrier (inauguration 10.6.1964), which during 1972-2015 conveyed about $15 \mathrm{~km}^{3} \mathrm{~m}^{3}$ water (about 4 times the lake volume) from Lake Kinneret to the central and southern parts of the country. It was part of the National Water supply design in the past, and onwards anticipated. The objectives of the present paper are to evaluate three major long term aspects of natural and anthropogenic events carried out in the Lake Kinneret Kinneret and its drainage basin with respect to ecological services supply of the ecosystems presented in separate chapters: Climate Change and its impact on Regional Water Balance with consequences on Anthropogenic Consumption and the Policy of Land-Use.

\section{Geography, Geology, and Geobotany [3] [4]}

Lake Kinneret watershed is part of the Northern section of the Syrian-African great rift Valley. The Lake Kinneret Watershed area $\left(2730 \mathrm{~km}^{2}\right)$, from Kinarot Valley in the south to Upper Galilee (northeastern Israel) and southern Anti-Lebanon in Lebanon is stretched between $32^{\circ} 40^{\prime}$ and $33^{\circ} 38^{\prime}$ North, $110 \mathrm{~km}$ long N-S axis. Maximum width is $50 \mathrm{~km}$ in the lake area and $15 \mathrm{~km}$ in its nor- 
thernmost region. The Kinneret drainage basin has a high range of landscapes, vegetation, soil and geological formation varieties as well as high altitude gradient: from +2814 (masl) to $208.2-214.87$ mbsl. The northern boundary of the Hula Valley is Mount Hermon, an uplifted massif of Jurassic and Lower Cretaceous limestone. The major headwater stored sources are formed in the mountain Rocky Karst. The Hermon Mountain is covered by sparse low trees. Hula Valley is bordered on its eastern side by the basalt-covered Golan Heights. During the 1880s, dense forest trees covered the western slopes of the Golan of which only a few remnants survived with the exceptional southern Yahudyia Forest Park (Kaplan 2006). The ridge of Naftali Mountain demarcates the western side of the Hula Valley. These northern faulted mountainous chains comprised of Cretaceous and Eocene limestone forming a steep escarpment up to an altitude of $900 \mathrm{~m}$. The central part of the Kinneret watershed side is a Karstic depression (500 - 600 masl) covered by thin basalt layer and reddish-brown terra-rosa soils suitable for plantation. The southern part of this area consists of the Safed-Meron Mountains reaching an altitude of $1200 \mathrm{~m}$. The central part of the northern region is the Hula Valley (70 - 90 masl) covered by 1000 - $1500 \mathrm{~m}$ thickness of deposited sediments. The mountainous drainage basin of the Hermon $\left(788 \mathrm{~km}^{2}\right)$ is the northern part of the drainage basin is an uplifted massif of Jurassic and Lower Cretaceous limestone comprising the highest (summit 2814 masl) peak of the watershed. The plant distribution is governed by altitude level. From the bottom of the mountain foothill up to 1400 masl dominancy of Oak (Quercus spp) spars forest; between 1400 - 1800 masl spars cover by Oak trees and bushes strongly impacted by anthropogenic destruction; above 1800 masl kind of Alpine vegetation of low sub-bush plants.

Schumacher [5] documented geographical observations in the Jaulan (Golan) region. He explored the Golan region on behalf of "The German Society for the exploration of the Holy Land" during 1883-1885. In the report that was published "Across the Jordan" in 1888, he confirmed that shortly earlier, "Stony Jaulan (Golan) has been covered with thick growth of forest trees; the still extensive oak (Quercus) woods... and the beautiful oak trees which singly and in groups...in the north of the Batihah (Beteicha, Bethsaida Valley) and Pitavia (Pistacia) in the vicinity of the oaks..." Schumacher (1888) also indicated the absence of wood growth (Forest) in the southern high plateau, which has probably been under deforestation. In his textbook of Geo-botany, Zohary [6] also has indicated that the Association of plant type of Forest is no more distributed in Israel except for several group residues of Pines in the upper Galilee whilst the Kinneret watershed was not mentioned. The Pine deforestation was mostly due to agricultural soil suitability of Randzine, which is preferred by Pine trees. [6] also mentioned the residue of groups of trees in the Kinneret watershed on the High altitude of the western mountains of the Upper Galilee. The low densities of low trees as Pistacia and Ziziphus in the southwestern "Lower Galilee" were also indicated by Zohary [6]. An area of $66.2 \mathrm{~km}^{2}$ located northeast of 
Lake Kinneret is presently a Nature Reserve, namely, Yahudia Forest [7] [8]. This region is covered with vegetation complexes (biocenosis) comprised of several plant associations presently legislatively claimed (declared) as Forest Park (Quercus sp., Pistacia sp., Styrax sp.). Kaplan [7] indicated this forest as a remnant of much larger woodland [5]. Kaplan [7] and unpublished, and [8] indicates forest/groove deciduous vegetation, including $518 \times 10^{3}$ trees covering an area of $66.2 \mathrm{~km}^{2}$, located in the southeastern region of the Kinneret Basin (Yahudiye Forest Park). Vegetation analysis of this plant community documented about 12 different plant associations within the Yahudiya Forest Park (Kaplan unpublished data): Five have a deciduous tree dominancy and the others are inhabited by bushes, perennial herbs and grass.

\section{Material and Methods}

This study represents an insight into the water balance of the Lake Kinneret watershed, the impact of consumption on the lake and the hydrological consequences of the Kinneret water budget. The data was provided by the Agriculture Ministry, the National Water Authority, The Israeli Hydrological Service, Kinneret Limnological Laboratory, Mekorot Water Supply Co., Hula Project Monitor Center Migal Scientific Research Institute and the Israeli Meteorological Service.

Meteorological Survey in the Lake Kinneret drainage Basin was carried out as regional survey of the Ministry of Agriculture, the National Water Authority and the National Meteorological and Hydrological Services of Israel (Dafna and Hula "Gadash" Stations) and Hula Project Monitoring System, MIGAL, Scientific Research Institute. Hourly Radiation data were monitored by Pyranometer Kipp and Zonen CM6. Accumulated Hourly data were averaged to daily, monthly and annual means. The units used in this paper are $\mathrm{MJ} / \mathrm{m}^{2} /$ day $\left(10^{6} \mathrm{Joules} / \mathrm{m}^{2} /\right.$ day $)$ where: Kcal as: $239 \mathrm{Kcal} . / \mathrm{m}^{2} /$ day).

\section{Results and Discussion}

\subsection{Water Consumption}

The available information presented in this paper is due to the Israeli part of the Kinneret Watershed which comprises about $73 \%\left(2000 \mathrm{~km}^{2}\right)$ of the total $(2730$ $\mathrm{km}^{2}$ ). The Information that was submitted by regional and national water authorities indicates the following: Until the late 1990s, the total legislated water allocation to this part of the Kinneret watershed ranged between 100 and 120 $\mathrm{mcm}\left(10^{6} \mathrm{~m}^{3}\right)$ per year for agriculture and domestic consumption (Table 2). Later on, a further downward restriction to $85 \mathrm{mcm} / \mathrm{y}$ was implemented. As a result of a long-term drought (2014-2018), restriction was lowered to a level of $68 \mathrm{mcm} / \mathrm{y}$ with additional supply from Lake Kinneret to the Golan Heights of 19 $\mathrm{mcm} / \mathrm{y}$. Irrespective to this solid documented information representing decline of water consumption [2] and Table 2 published results of Landsat images evaluation indicating increase of potential water consumption in the Upper Jordan watershed from 119 in 1984 to $178 \mathrm{mcm} / \mathrm{y}$ in 2017. 


\subsection{Land-Use Policy within the Watershed Area}

For the outline of regional Evapo-transpiration water loss, a GSI map of Land Use as of 2004 was charted. The information covers Israeli territorial land (2000 $\left.\mathrm{km}^{2} ; 73 \%\right)$ within the total Kinneret watershed $\left(2730 \mathrm{~km}^{2}\right)$. The results are given in Table 1 and Figure 1.

Results in Table 2 indicate a significant deficit (3821 minus $2034=1787 \mathrm{mcm} / \mathrm{y})$ of rainfall water supply to cover the maximal potential Evapo-transpiration demand.

A brief summary of an International Conference about Land-Use Land-Cover has been recently published. It is a topic that is under a wide scientific research [9]: "Forestation, fallow management and agricultural and pasture management are known as reducer of greenhouse gas emission" [10].

It is a moderately accepted policy of land use by no incentive to destroy natural (Virgin) forest or to convert them into biomass plantations with low value of nature conservation and biodiversity protection.

Since the 1950's the region of Amazonia in South America has been associated

Table 1. Land use in the Israeli territorial part of the Kinneret Watershed during 2004 as evaluated from Figure 1.

\begin{tabular}{cc}
\hline Type of Land Cover & Area $\left(\mathrm{km}^{2}\right)$ \\
\hline Field Crops & 180 \\
Orchards & 197 \\
Fishponds, reservoirs, Agmon, Lake Kinneret & 171 \\
Natural Forest and Grove & 266 \\
Not Cultivated land & 1067 \\
Other & 111 \\
Total & 1992 \\
\hline
\end{tabular}

Table 2. Annual (1999) water consumption $\left(\mathrm{mcm} ; 10^{6} \mathrm{~m}^{3}\right)$ in Upper Galilee Region. Data Source: I. Chen, Galilee Officer, Agricultural Ministry; N. Schatz, Upper Galilee Municipality-Agricultural Corporation.

\begin{tabular}{ccc}
\hline Consumer & Total Area $\left(10^{3} \mathrm{~m}^{2}\right)$ & Annual Consumption $(\mathrm{mcm} / \mathrm{y})$ \\
\hline Deciduous Fruit Trees & 38,504 & 27 \\
Citrus Fruit Trees & 6641 & 4.6 \\
Sub-tropical Fruit Trees & 10,019 & 11 \\
Other Orchards & 1000 & 0.7 \\
Irrigated, Field Crops, Vegetable & 99,000 & 49.5 \\
Rain-fed Field Crops & 0 & 0 \\
Aquaculture & 4000 & 7.2 \\
Milk Cattle Forage & 3273 & 1.6 \\
Meat Cattle Fooder & 6378 & 0.6 \\
Domestic Supply & & 1.04 \\
Total & & 103.2 \\
\hline
\end{tabular}




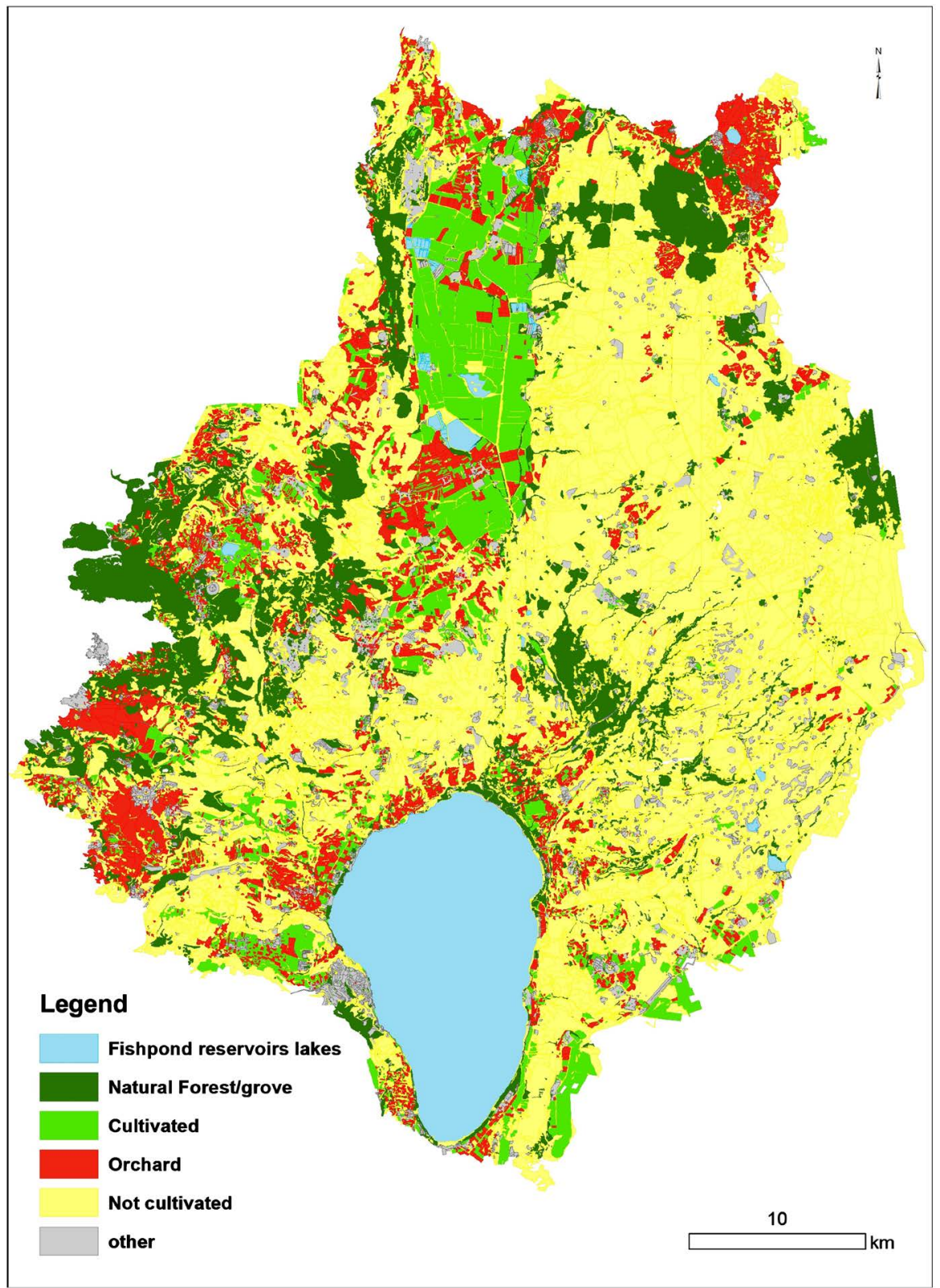

Blue: Water Covere: Agmon, Fish ponds reservoirs, Hula Nature Reservation Lake Kinneret (majority of 98\%). Dark Green: Natural Forest/Grove/Orchards (Deciduous and Evergreen (including Yahudiya "Forest Park"; see text). Brown-Reddish: Orchards: Deciduous and Evergreen). Light Green: Cultivated-Irrigated Field Crops. Yellow: Not Cultivated (covered and un-covered grass).

Figure 1. GIS (Geographic Information System) map of land-use on the Israeli part of the Lake Kinneret watershed in 2004 (IMC 1999).

with a huge increase in the extent and rate of deforestation area cover, approximately $500,000 \mathrm{~km}^{2}$. Current rates of annual deforestation range between 15,000 and $20,000 \mathrm{~km}^{2}$, causing changes in water budgets as well as a decrease in rainfall following the replacement of forests by pasture. It was widely documented [11] [12] [13] [14] [15]. Several surface characteristics such as albedo, rainfall, and interception loss dynamics were quantified for the surface cover of forest, bushes, grass (pasture) or uncultivated land. Forest cover surface shows no distinct 
seasonal trend of evaporation, whilst other types of cover or uncovered soil surface do. Moreover, during the dry season, pasture exhibits moisture stress due to their shallow root penetration whilst forest may suck water from deep layers of soil moisture [15].

There is a coupling between soil surface and the climate as mediated by water cycles [9]. The intensity of such dependence might be varied in relation to type and cover density of vegetation.

\subsection{Regional Water Balance: Evapo-Transpiration (ET) Water Loss and Consumption}

The information given in Table 3 called for an obvious question: How does agricultural management "absorb" such constraints of drought and legislated water supply restriction? The answer is partly given in an Interim Report [16]: during 20 years (1990-2010) the efficiency of water utilization aimed at the beneficial revenue of agricultural production was doubled from 4110 to 8142 US\$ per $10^{3} \mathrm{~m}^{2}$ (dunam). It was implemented as a result of significant agricultural technological improvements. The maintenance of efficient agricultural production was implemented by technological improvement, and blaming farmers for surplus consumption of water resources is an incorrect consideration. Moreover, water balances conditions where the rainfall budget source is balanced only by runoff, and ET (as common in tropical or temperate regions) is not relevant to the Kinneret watershed where significant quantities of contributed rainy waters are migrated into the unknown underground spaces [17] [18] [19]. The accurate and long-term record of river discharge and rainfall amount in the Kinneret watershed combined with water level fluctuations accompanied by disputed information of water utilization require priority grading and dependence relations. Undoubtedly, the most important and significant variable of regional water balance is rainfall. If the climate is changed, and therefore, water consumption and possibly land use policy reduces, it will have a significant impact

Table 3. Regional sub-units of the Lake Kinneret drainage basin and their surface area calculated total rainfall volume and annual potential maximum evaporation based on Penman-Witheise measures (averaged for 2010-2015) of $1404 \mathrm{~mm} / \mathrm{y}$.

\begin{tabular}{ccccc}
\hline Geographical Region & $\begin{array}{c}\text { Regional } \\
\text { Surface Area } \\
\left(\mathrm{km}^{2}\right)\end{array}$ & $\begin{array}{c}\text { Average Regional } \\
\text { Annual Rainfall } \\
(\mathrm{mm} / \mathrm{y})\end{array}$ & $\begin{array}{c}\text { Annual regional Maximum Potential: } \\
\text { Rain Volume } \\
(\mathrm{mcm} / \mathrm{y})\end{array}$ & $\begin{array}{c}{ }^{*} \text { Evaporation } \\
(\mathrm{mcm} / \mathrm{y})\end{array}$ \\
\hline Eastern-Northern Galilee & 542 & 800 & 434 & 758 \\
Hermon-Jordan & 788 & 900 & 709 & 1103 \\
Hula Valley & 200 & 450 & 90 & 280 \\
Golan Height & 580 & 900 & 522 & 812 \\
Western Basin & 450 & 450 & 202 & 630 \\
Small Southern Basins & 170 & 450 & 77 & 238 \\
Total & 2730 & $($ Mean: 658$)$ & 2034 & 3821 \\
\hline
\end{tabular}

*Based on: $1404 \mathrm{~mm} / \mathrm{y}$. 
on the end product of the drainage-lake water level. The second level of importance is due to Evapo-transpiration (ET). This variable of the regional water balance is strongly affected by climate conditions, land plant cover, water availability and soil features. Soil moisture reduction, which is strongly affected by land use policy and, therefore, climate change, might also reduce evaporation rate. Nevertheless, land use-land cover policy is controlled by human activity (anthropogenic). The degree of creditability given to the final conclusion is dependent on data totality and precision. Several studies documented climate change as a result of afforestation (Plantinga and Mauldin 2001; Rabbinge et al. 1993).

Water loss by Evapo-transpiration is directed through three major channels: 1) directly from soil to the atmosphere; 2) sucked by plant root system and transported upwards through pits to the atmosphere-Transpiration; and 3) touching plant canopy (leaves, branches) and immediately evaporating to the atmosphere-Interception Loss (IL). Among those three ingredients, the most important in plant-covered land-use in the Kinneret watershed is transpiration. The most important impact on ET is given by the air temperature and, therefore, the runoff is the result of the difference between rainfall and ET [20]. Moreover, climate change may cause changes in rainfall frequency and intensity, which might have a significant impact on IL's quantity. Documentation of climate change expression as a combination of rainfall and wetter winters and drier summers caused by evaporation is provided by [21]. Reynard et al. [21] also indicated that rainfall intensity and distribution mainly determined the hydrological response of a watershed. [9] concluded that natural watershed ecosystems are mostly well balanced. Nevertheless, minor effects are to be expected on water balance caused by ET alteration caused by land-use changes. It is suggested that recently modified climate conditions, i.e. rainfall decline, combined with a long history of deforestation and shorter implementation of vegetation-covered land-use policy, promoted water input decline in Lake Kinneret and resulted in WL lowering.

Results in Table 4 indicate a reduction of Water-Swampy-Flooded area from $100 \%$ occupation to less than $5 \%$ cover.

Comparative land-use management between two years of 2004 and 2019 is shown in Table 5. Surface area that is water cover indicates as $171 \mathrm{~km}^{2}$, while in Table 5 it is only 8.1 because the surface area of Lake Kinneret $\left(168 \mathrm{~km}^{2}\right)$ was eliminated as not being anthropogenic land-use.

Results in Table 5 indicate a reduction of agricultural land-use in the Kinneret Watershed whereas crops and financial benefit per areal unit were improved simultaneously with a reduction of water consumption (from $110 \mathrm{mcm} / \mathrm{y}$ to 68 $\mathrm{mcm} / \mathrm{y}$ ). Reduction of water consumption when the benefit was enhanced is the result of technological improvements. The possibility of beneficial agricultural development in the Kinneret drainage basin was the result of improvements in water utilization efficiency. The management of water balance in the Kinneret 
Table 4. Land use land cover of $59 \mathrm{~km}^{2}$ of the Hula Valley previously $(<1958)$ covered by seasonally flooded, permanently swampy and old Lake Hula. Numbers are $\mathrm{km}^{2}$ and $\%$. Historical events of Anthropogenic intervention: 1952-1957 Drainage and conversion to agricultural management; 1989-1995-Hula project implementation.

\begin{tabular}{cccccc}
\hline Used-cover type & 1949 & 1958 & 1976 & 1986 & 2010 \\
\hline Water & $14(24 \%)$ & 0 & 0 & $1(2 \%)$ & $1(2 \% 0$ \\
Swamps & $32(54 \%)$ & $4(7 \%)$ & $4(7 \%)$ & $2(3 \%)$ & $4(7 \%)$ \\
Flooded & $13(22 \%)$ & 0 & 0 & 0 & 0 \\
Field Crops & 0 & $35(59 \%)$ & $46(79 \%)$ & $34(58 \%)$ & $40(68 \%)$ \\
Uncultivated & 0 & $10(17 \%)$ & - & $8(14 \%)$ & $3(5 \%)$ \\
Other & 0 & $5(8.5 \%)$ & $2(3 \%)$ & $6(10 \%)$ & $4(7 \%)$ \\
Orchards & 0 & 0 & $2(3 \%)$ & $5(8 \%)$ & $6(9 \%)$ \\
Fish Ponds & 0 & $5(8.5 \%)$ & $3(8 \%)$ & $3(5 \%)$ & $1(2 \%)$ \\
Total & 59 & 59 & 59 & 59 & 59 \\
\hline
\end{tabular}

Table 5. Comparative agricultural land use (in $\mathrm{km}^{2}$ ) over Israeli territorial land (2000 $\left.\mathrm{km}^{2} ; 73 \%\right)$ within the entire Kinneret Drainage Basin $\left(2730 \mathrm{~km}^{2}\right)$ between 2004 and 2019.

\begin{tabular}{ccc}
\hline & $\mathbf{2 0 0 4}$ & $\mathbf{2 0 1 9}$ \\
\hline Field Crops & 180 & 117 \\
Orchards & 197 & 208 \\
Fishponds, Agmon & 8.1 & 4.6 \\
Total & 385.1 & 329.6 \\
\hline
\end{tabular}

watershed was efficiently managed to follow national demands for drinking water supply from Lake Kinneret as affected by climate change. It was attached to the administrative adaptation to actual conditions through achievement controlled by three crucial parameters: 1) climate conditions (rainfall intensity); 2) demands for reasonable agricultural revenue; and 3) national demands for water supply. Water-saving in the drainage basin was included among emergent achievements aimed at slowing down the rate of Kinneret WL decline during an unusual periodical (2014-2018) drought.

A GSI map of Land Use in 2004 was charted (Figure 1). The information covers the Israeli part of land $\left(2000 \mathrm{~km}^{2} ; 73 \%\right)$ within the total Kinneret watershed $\left(2730 \mathrm{~km}^{2}\right)$. The results are shown in Table 1 and Figure 1.

The following are the annual values of different Land-Use-Land-Cover and ET type capacities, which are acceptable worldwide:

Grass Field Crops (Wheat) $-417 \mathrm{~mm}$

Orchard (deciduous and evergreen) $-300 \mathrm{~mm}$

Natural forest and Grove (subtropical) $-279 \mathrm{~mm}$

Partly and full grass cover uncultivated- $-318 \mathrm{~mm}$

Reservoirs, fishponds, Lake Agmon—1981 mm

Incorporation of these ET measures with data given in Table 5 [22] [23]. The 
regional ET capacities during 2004 were evaluated; results are shown in Table 6.

Data in Table 6 indicates that water consumption in the Israeli part of the Kinneret Watershed is divided as follows: $27 \%$ or $17 \%$ (Total-555; Lake Kinneret excluded-347 from 2034) of rainfall water resource is Evapo-transpiration and $70 \%$ is the total of runoff and underground. With respective consideration to the seasonal Landsat images ET annual water consumption during 2004 was maximum 555 and minimum $347 \mathrm{mcm}$.

A significant exceptional factor is not considered in Table 6: seasonality of agricultural crop corrections is shown in bold.

For the evaluation of seasonal water consumption, two Landsat images were charted and aerial land use was computed during October 2018 (summer-fall season) and February 2019 (winter-spring season). Results are shown in Table 7 and Figure 6.

Data shown in Table 7 indicates that cultivated grass-covered area (no trees) (wheat or corn) should be considered as water ET consumers during half a year only. ET water utilization in uncultivated area is validated also during 6 winter months only. Information given by Kaplan [7] (and unpublished) [8] indicates that forest/groove deciduous vegetation of $518 \mathrm{X} 10^{3}$ plants covering an area of $66.2 \mathrm{~km}^{2}$, located in the southeastern region of the Kinneret Basin (Yahudiye Forest Park), consumes annually ET waters throughout full-year cycle ranged between 14.5 and $18.510^{6} \mathrm{~m}^{3}$. It is considered when the annual total ET capacity of an Oak tree is $0.279 \mathrm{~mm}$ and one Oak tree canopy cover is $100 \mathrm{~m}^{2}$.

Table 6. Land-use-surface area $\left(\mathrm{km}^{2}\right)$ respective annual ET volumes $(\mathrm{mm})$ and total capacities $(\mathrm{mcm} / \mathrm{y})$ in the Israeli part of the Kinneret watershed during 2004 (values shown bigger and bold indicate lower seasonal, 6 month value).

\begin{tabular}{cccc}
\hline Land Use Type & Surface Area $\left(\mathbf{k m}^{2}\right)$ & Annual ET $(\mathbf{m m})$ & Regional Annual ET Capacity (mcm/y) \\
\hline Partly and full grass cover uncultivated & 1067 & 318 (6 winter months: 159) & 340 (6 winter months: 170) \\
Orchard (deciduous and evergreen) & 197 & 300 & 60 \\
Grass Field Crops & 180 & 417 (6 summer months: 208$)$ & 75 (6 summer months: 37$)$ \\
Reservoirs, fishponds, Agmon (Exc.L. Knneret) & 3 & 1981 & 6 \\
Natural forest/Grove & 266 & 279 & $545(347)$ \\
Total & & & 54 \\
\hline
\end{tabular}

Table 7. Surface area $\left(\mathrm{km}^{2}\right)$ computation from Landsat images during October 2018 and February 2019 (Figure 6): Source: Landsat Images from:

(https://en.wikipedia.org/wiki/Sentinel-2; developed by: ArcView-ESRI).

\begin{tabular}{ccc}
\hline Landuse/Cover & October 2018 & February 2019 \\
\hline Fishponds Reservoirs, Agmon, Hula Reservation Lake Kinneret & 171 & 171 \\
Orchard & 356.3 & 356.3 \\
Not cultivated/grass covered & 152.4 & 1320.9 \\
Not cultivated/grass uncovered & 1312.2 & 143.7 \\
Total & 1992 & 1992 \\
\hline
\end{tabular}




\subsection{Climate Change}

\subsubsection{Rain and River Discharges}

\section{Brief History (1970-2018) of W1 Fluctuations in Lake Kinneret (Figure 2)}

A daily monitor of WL measurement record of Lake Kinneret has been available since 1926. The close relation between Kinneret WL and precipitation and discharge regimes in the watershed is presented in Figure 3 and Figure 9. Historical (9000 years before present) data of the Kinneret WL is summarized in Figure 5. Two different methods: 1) distribution of algal fragments in sediment cores dated layers, and 2) granulometric analysis of dated geological layers [24] [25] documented that during the last 9000 years Kinneret WL fluctuated within

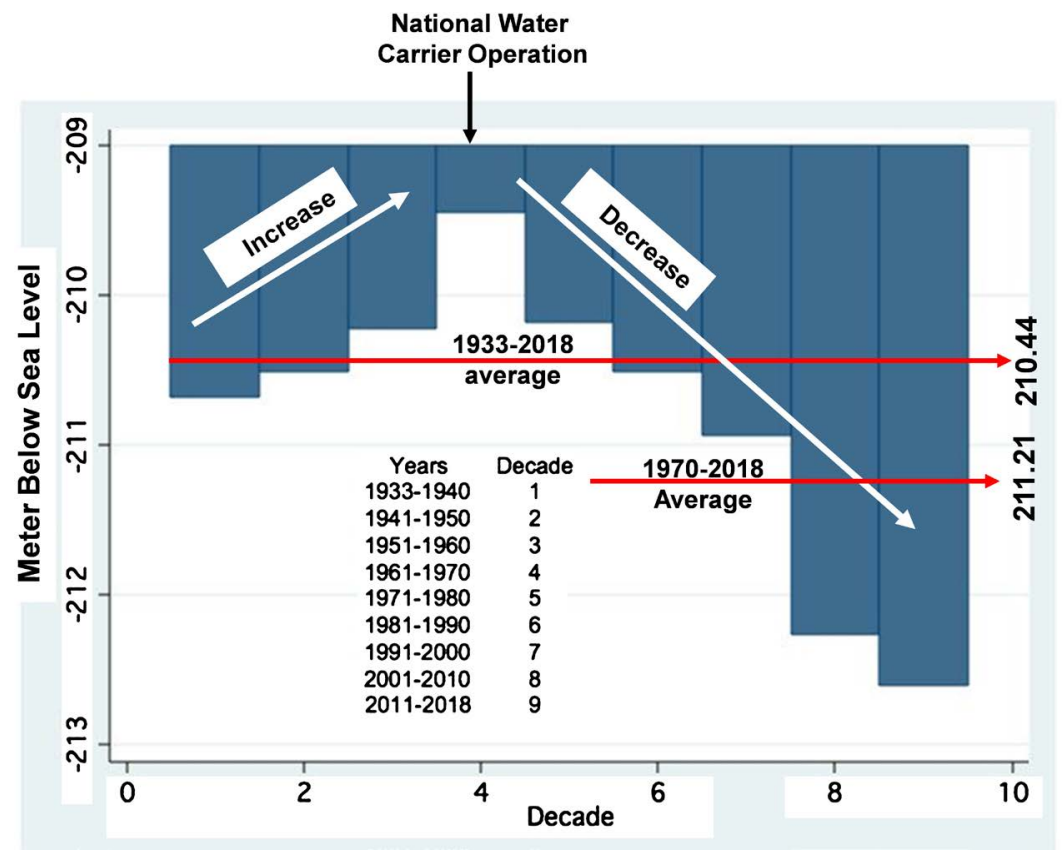

Figure 2. 10 (decades) year averages of monthly averages of water level in Lake Kinnere.

Trend of changes, periodical means, and anthropogenic events are indicated.
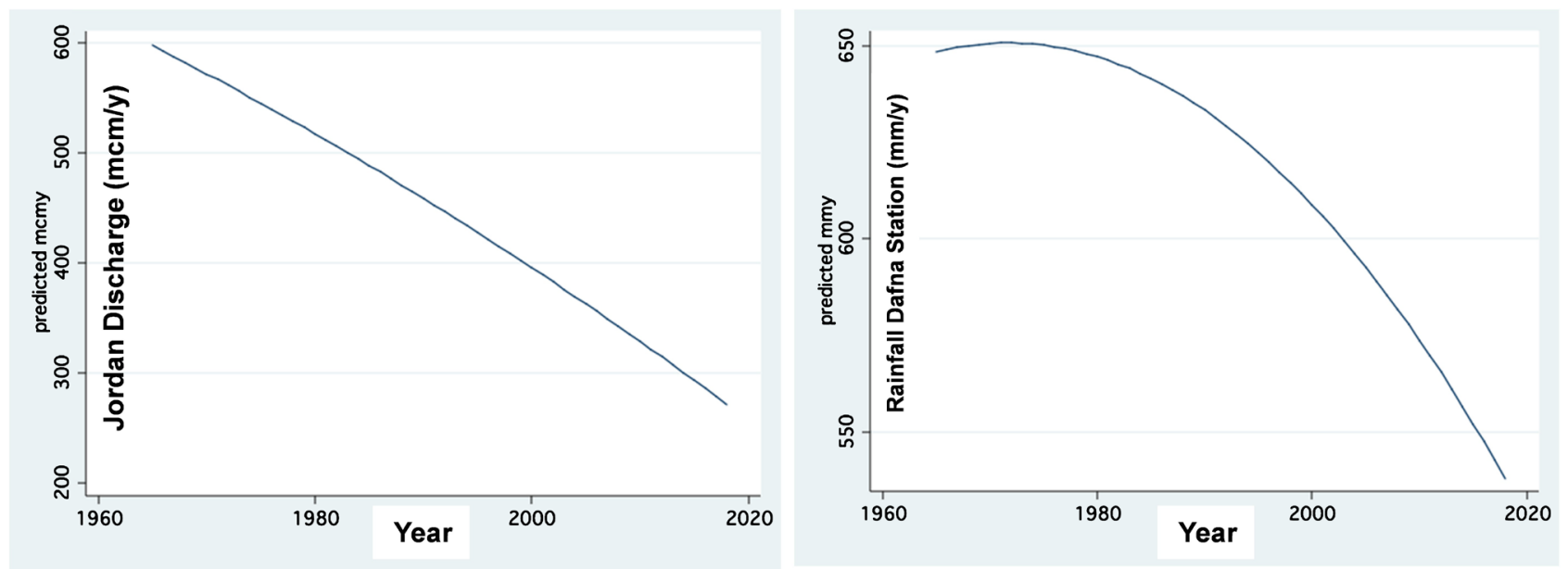

Figure 3. Fractional polynomial regression plot of annual Jordan discharge ( $\mathrm{mcm} / \mathrm{y})$ (left panel) and rainfall (mm/y) (Dafna Station, right panel) during 1969-2018. 

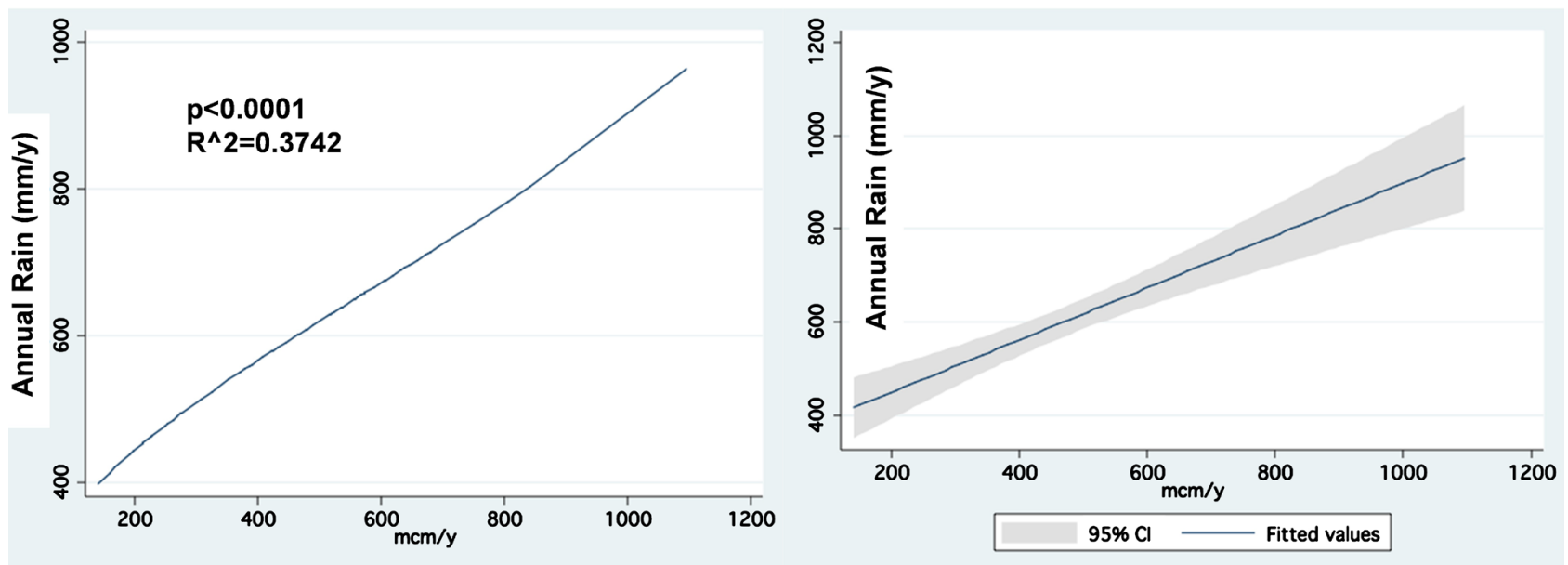

Figure 4. Linear regression (right panel: CI 95\%) ( $\mathrm{r}^{2}$ and p values are given: left panel) between rainfall (mm/y; Dafna station) and Jordan discharge $(\mathrm{mcm} / \mathrm{y})$ during 1940-2018.
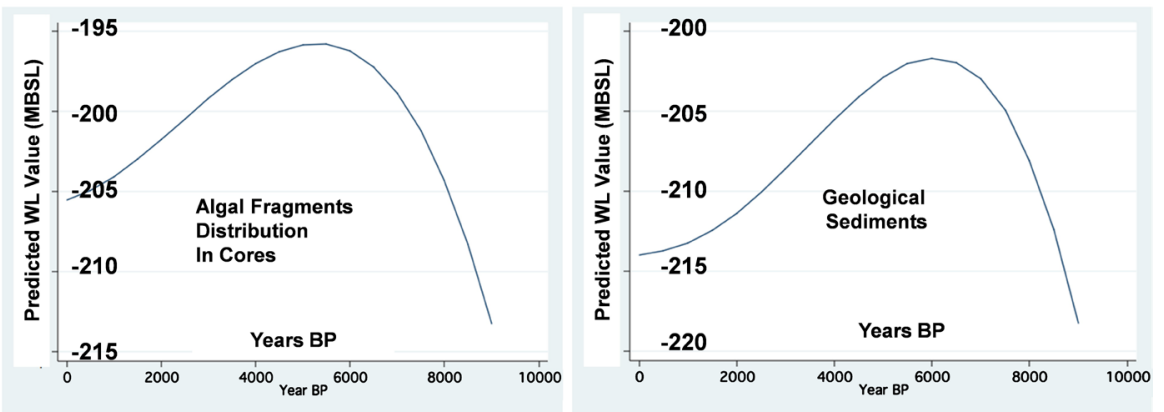

Figure 5. Lake Kinneret water level historical record defined by two methods: algal fragments distribution in sediment core (left panel) and granulometric analysis in geological formations (right panel) from 9000 years before to present.

an amplitude of 20 meters (197 - 217 mbsl). Anthropogenic control of water balance became possible after the construction of the south dam. The beginning of intensive consumption of Kinneret water (early 1970's) was implemented as a consequence of the operation of the National Water Carrier (10.6.64) (Figure 4). Therefore, for the study of the impact of water resources on Kinneret WL, the temporal analysis was initiated in 1970. The daily measurements of WL were condensed into monthly averages. During 48 years (576 months; 1970-2018), there were only 97 months (17\%) with WL lower than the legislated bottom line of $213 \mathrm{mbsl}$ and the upper legislated WL line is $208.80 \mathrm{mbsl}$.

Cases of exceptionally low WL were recorded only during 18 recent years. Moreover, during this period only in half of it (9 years; 50\%) WL below $213 \mathrm{mbsl}$ was recorded. The distribution of monthly means of WL ranges ( $1 \mathrm{~m}$ intervals) is shown in Table 8.

Results in Table 8 prominently indicate that during 1970-2018, in spite of climate change, agricultural management and technological modifications, most of the time (83\%) the Kinneret WL was not lower than the legislated altitude of 213 mbsl. Moreover, until the 2000's WL was higher than the minimal legislated 
Table 8. The distribution of number of months with monthly means (see text) of WL ranges (1 $\mathrm{m}$ interval) in Lake Kinneret during 1970-2018.

\begin{tabular}{cc}
\hline WL Range (mbsl) & Number of Months (\%) \\
\hline Below 214 & $32(6)$ \\
$214-213$ & $65(11)$ \\
$213-212$ & $89(15)$ \\
$212-211$ & $104(18)$ \\
$211-210$ & $144(24)$ \\
$210-209$ & $125(21)$ \\
Above 209 & $30(5)$ \\
\hline
\end{tabular}

altitude. The decline of WL below the instructed WL bottom line $(213 \mathrm{mbsl})$ was recorded during years of exceptional decline of rainfall: 2000-2002, 2008-2011, and 2016-2018, which consequently resulted in significant restriction of agricultural water allocation by the National Water Authority.

Results shown in Figure 3 indicates decline of rainfall and Jordan River discharges during the last 40 years. Givati and Rozenfeld [26] and [27] documented significant decline of rainfall in the Kinneret Watershed (Figure 4) and consequently exceptional reduction of river discharge capacities. They [26] [27] indicated historical deficiency of aquifers storage in the Northern Basin since 100 years. Moreover, during 2013/14 and 2015/16 hydrological seasons rainfall was $47 \%$ and $68 \%$ respectively below the multiannual mean. The discharge of Rivers Dan and Banias during 2014 (2.67 and $0.16 \mathrm{~m}^{3} / \mathrm{s}$ respectively) were the lowest since recent 22 years whilst maximum discharges were 12.8 and $7.4 \mathrm{~m}^{3} / \mathrm{s} \mathrm{respec-}$ tively. The extremeness of climate change was indicated by the annual discharge record of the principle output of water flow from the watershed - River Jordan downstream as shown in Figure 3. Major contributors to the Jordan outflow are Dan and Banias rivers. The annual discharges in those rivers declined by 63 and $14 \mathrm{mcm} / \mathrm{y}$ respectively. Moreover, linear regression line between availability of Kinneret waters $(\mathrm{mcm} / \mathrm{y})$ and Years (1985-2016) indicates decline from 470 to $225 \mathrm{mcm} / \mathrm{y}$. These data are controversial to [2] who claimed that there is no decreasing trend in inflow from the headwaters of the upper Jordan River. Moreover, the statement (Winn et al. 2019) that "rising temperatures in the basin may increase ET but are too small to explain the magnitude of observed discharge decreases" is misleading.

\subsubsection{Air Temperature}

A record of Maxima and Minima of air temperatures measured at the Meteorological Station Dafna located in the northern part of the Hula Valley are summarized in Figure 7 and Figure 8. Hourly measurements were averaged to daily and daily to monthly and monthly to annual means. These annual data were plotted as a Fractional Polynomial Regressions Vs Years (Figure 7, Figure 8). (1980-2019): Results indicate increase of air temperature during the last 40 years 

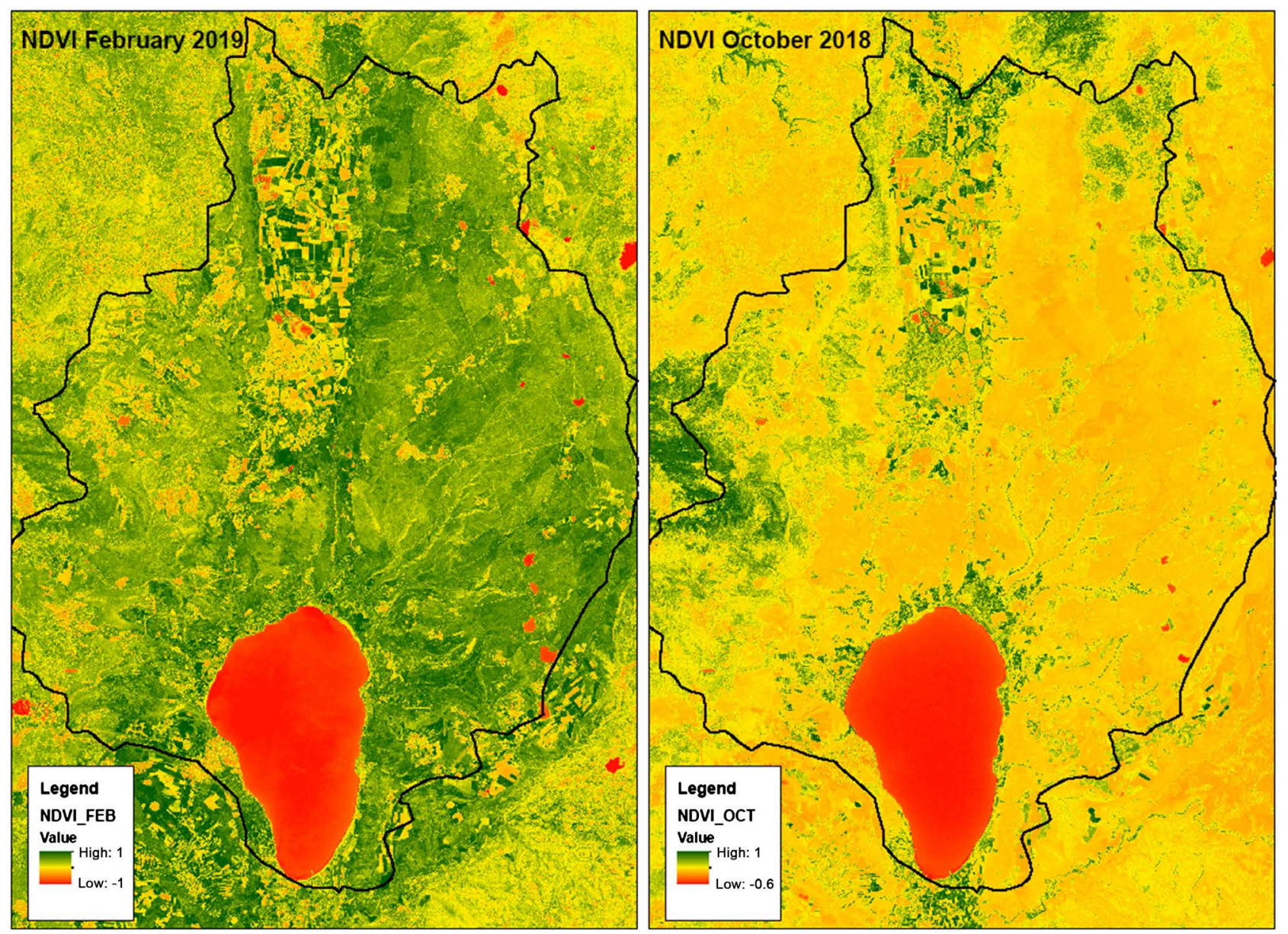

Figure 6. Wintertime (Left: February 2019) and summertime (Right: October 2018) Landsat-derived Normalized Difference Vegetation Index (NDVI) Imaginary demonstrating changes in plant and surface water (lakes, fish-ponds, reservoirs) land cover: green-plant surface cover; yellow-uncovered surface cover; red-water surface cover (see summary in Table 7). Geographically delineation of the Israeli Part of the Kinneret watershed is indicated.

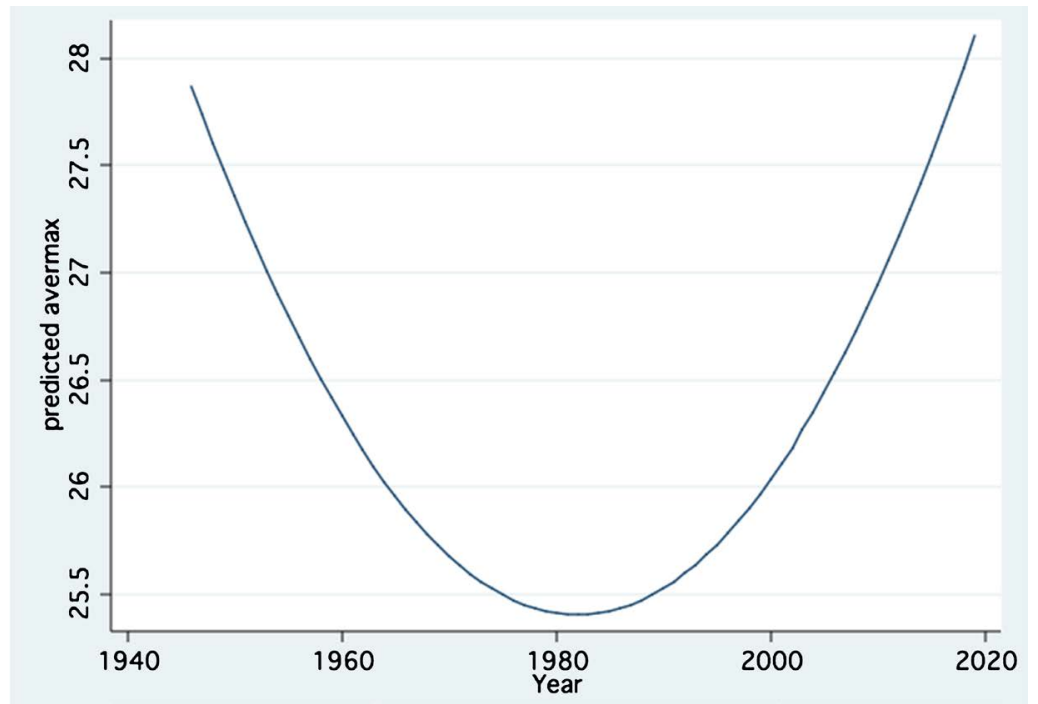

Figure 7. Fractional polynomial regressions between annual means of daily air maximum temperature measured in Dafna Station and years during 1946-2019. 
The annual maximum and minimum were elevated by $2.7^{\circ} \mathrm{C}$ and $1.5^{\circ} \mathrm{C}$ respectively.

\section{Solar radiation}

Data were collected in the Meteorological Station, namely, "GADASH", located in the central part of the Hula Valley during 1993-2019 (through July) and results are given in Table 9 and Figure 10.

Results in Table 9 indicate multiannual (1993-2019 through July) average of radiation as $4374 \mathrm{Kcal} / \mathrm{m}^{2} /$ day $\left(18.3 \mathrm{MJ} / \mathrm{m}^{2} /\right.$ day). Mean (1965-1975) $\mathrm{RAD}$ data documented in Lake Kinneret (Serruya $1978 \mathrm{~b}$ ) of $3600 \mathrm{Kcal} / \mathrm{m}^{2} /$ day is lower by $22 \%$ from those measured in the Hula Valley ( $25 \mathrm{~km}$ northern to Lake Kinneret) during 15 - 41 years later.

Maximum RAD value reported for Lake Kinneret [28] during 1965-1975 for

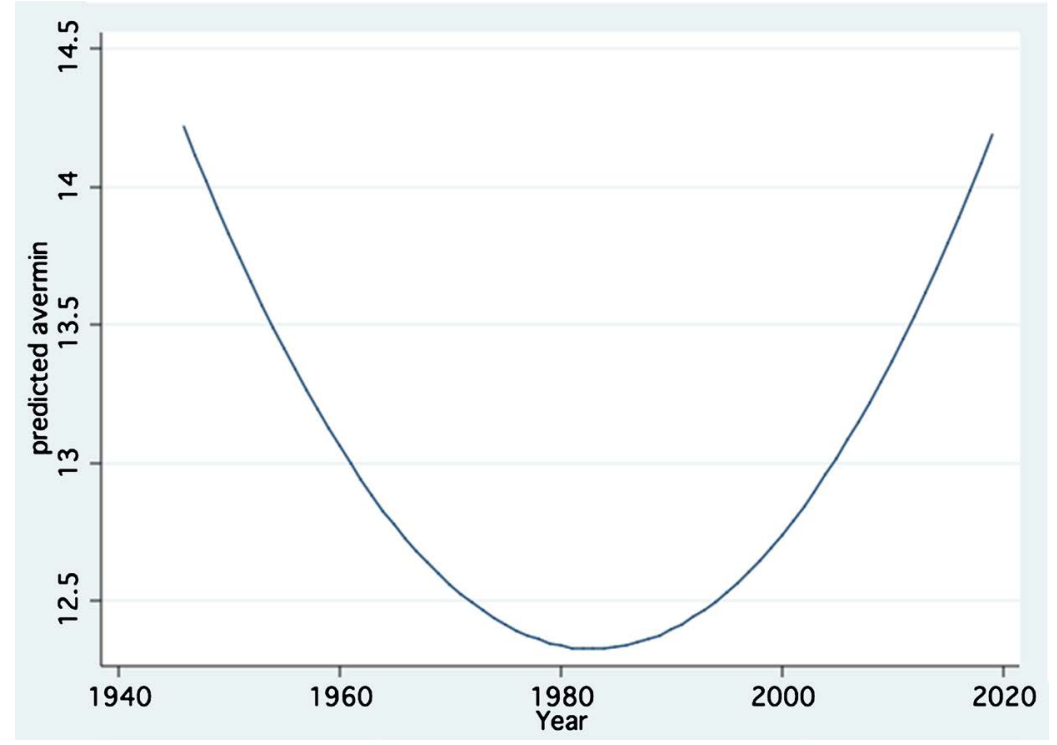

Figure 8. Fractional polynomial regressions between Annual means of daily air minimum temperature measured in Dafna Station and years during 1946-2019.
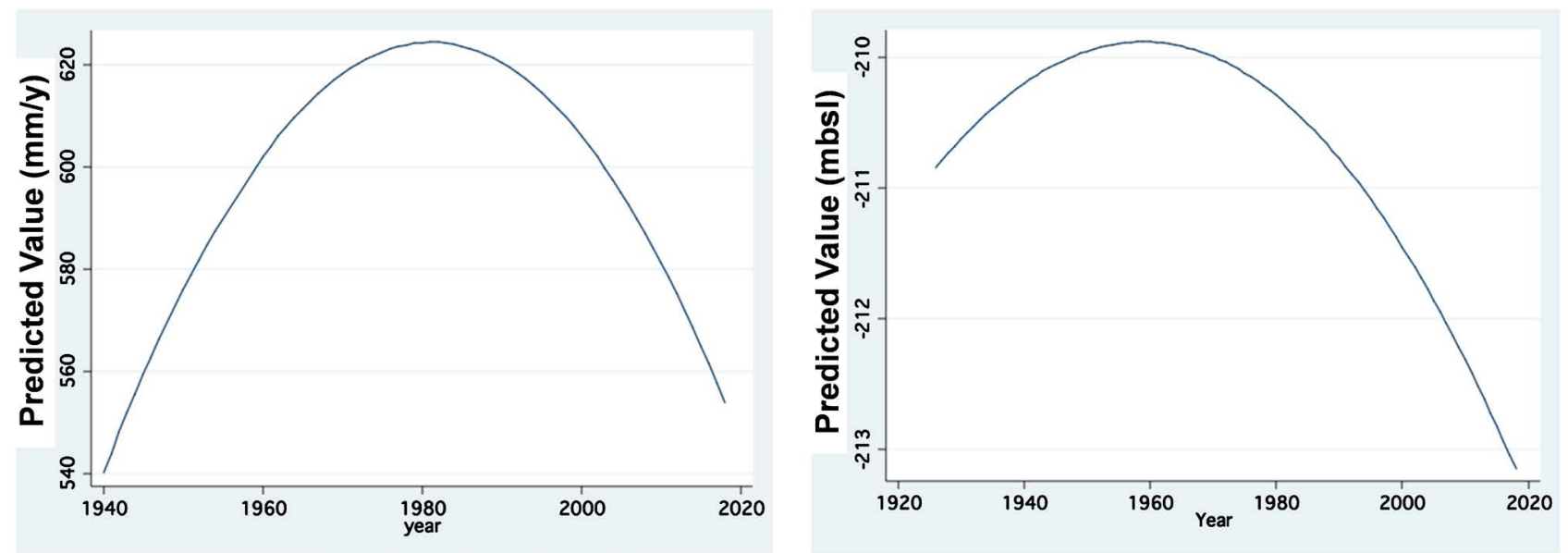

Figure 9. Fractional polynomial regressions of rainfall (Left Panel, Dafna Station, 1940-2018), and annual means of WL (mbsl) (Right Panel, 1926-2018) and years. 
Table 9. Annual means of daily solar radiation given in $\mathrm{MJ} / \mathrm{m}^{2} /$ day $\left(10^{6} \mathrm{~J} / \mathrm{m}^{2} / \mathrm{d}=239 \mathrm{Kcal} / \mathrm{m}^{2} / \mathrm{d}\right)$.

\begin{tabular}{|c|c|}
\hline Year & $\mathrm{MJ} \mathrm{m} / \mathrm{d}(\mathrm{Kcal} \mathrm{m} / \mathrm{d})$ \\
\hline 1993 & $19.2(4589)$ \\
\hline 1994 & $17.5(4183)$ \\
\hline 1995 & $19.2(4589)$ \\
\hline 1996 & $17.5(4183)$ \\
\hline 1997 & $17.3(4135)$ \\
\hline 1998 & $17.5(4183)$ \\
\hline 1999 & $18.4(4398)$ \\
\hline 2000 & $16.1(3848)$ \\
\hline 2001 & $19.6(4684)$ \\
\hline 2002 & $19.3(4589)$ \\
\hline 2003 & $18.3(4374)$ \\
\hline 2004 & $18.5(4422)$ \\
\hline 2005 & $18.8(4483)$ \\
\hline 2006 & $18.5(4398)$ \\
\hline 2007 & $18.1(4326)$ \\
\hline 2008 & $18.8(4469)$ \\
\hline 2009 & $18.34374)$ \\
\hline 2010 & $18.7(4469)$ \\
\hline 2011 & $17.9(4278)$ \\
\hline 2012 & $17.9(4278)$ \\
\hline 2013 & $18.4(4398)$ \\
\hline 2014 & $18.5(4422)$ \\
\hline 2015 & $17.9(4278)$ \\
\hline 2016 & $18.5(4422)$ \\
\hline 2017 & $18.6(4445)$ \\
\hline 2018 & $17.9(4278)$ \\
\hline 2019 & $18.8(4493)$ \\
\hline
\end{tabular}

summer bright (cloudless) conditions was $5800 \mathrm{Kcal} / \mathrm{m}^{2} /$ day whilst the Maximum summer (July) average and Minimum winter (January) values (1993-2019) were 6668 and $2247 \mathrm{Kcal} / \mathrm{m}^{2} /$ day. We calculated the impact of two climate factors impact on ET capacities (in $\mathrm{mm}$ ) by using two methods (Equations) (Howell and Evert 2004): Air temperature (AT) and Radiation (RAD). Results gave an indication that the impact of AT and RAD on ET capacity is approximated as $20 \%$ and $80 \%$ respectively. RAD and AT data for three months (July-September during 2001-2018) record including simultaneously collected AT and RAD measures were incorporated into Penman-Motheith equations (Howell and 
Evert 2004) and periodical accumulated ET ranges (mm) are given in Table 10.

Results in Table 10 represent accumulated impact in two periods and indicates similarity. Nevertheless, results given in Table 9 were regressed as Fractional Polynomial relations (Figure 10) between RAD and years and a slight increase of $1.3 \mathrm{MJ} / \mathrm{m}^{2} /$ day of radiation during $1995-2018$ was indicated in the Hula Valley. Moreover, results given in Figure 11 indicate positive relation between RAD and AT whilst, as likely predicted, inverse relation between air temperature and Relative Humidity. When air temperature was elevated from $15^{\circ} \mathrm{C}$ to $30^{\circ} \mathrm{C}$, radiation increased by $10 \mathrm{MJ}$ which might effectively cause an ET enhancement. The monthly change of radiation (Figure 12) prominently represents fluctuation range between $<10 \mathrm{MJ} / \mathrm{m}^{2} /$ day in winter and $27 \mathrm{MJ} \mathrm{MJ} / \mathrm{m}^{2} /$ day in mid-summer. Results in Table 10 show that the higher impact on ET is attributed to AT. We assume that the climate change in the Kinneret drainage basin as approved by prominent AT elevation and a slight RAD increase have an impact on water consumption through ET. Conclusively, the significant increase of Air temperature, slight elevation of RAD and the Rainfall reduction accompanied by river discharge reductions confirm climate change in northern Israel.

Winn et al. [2] are doubtful about climate change (global warming) impact on the water flows reduction into Lake Kinneret. Whilst, long term record of

Table 10. Periodical (1:2001-2003; 2: 2016-2018) summaries of total ET as calculated by the two methods: for AT, and for RAD. Results are given in ET mm.

\begin{tabular}{cccc}
\hline Period & AT $(\mathrm{mm})$ & RAD $(\mathrm{mm})$ & ET $(\mathrm{mm})$ \\
\hline $2001-2003$ & $300(16)$ & $1574(84)$ & 1874 \\
$2016-2018$ & $316(17)$ & $1572(83)$ & 1885 \\
\hline
\end{tabular}

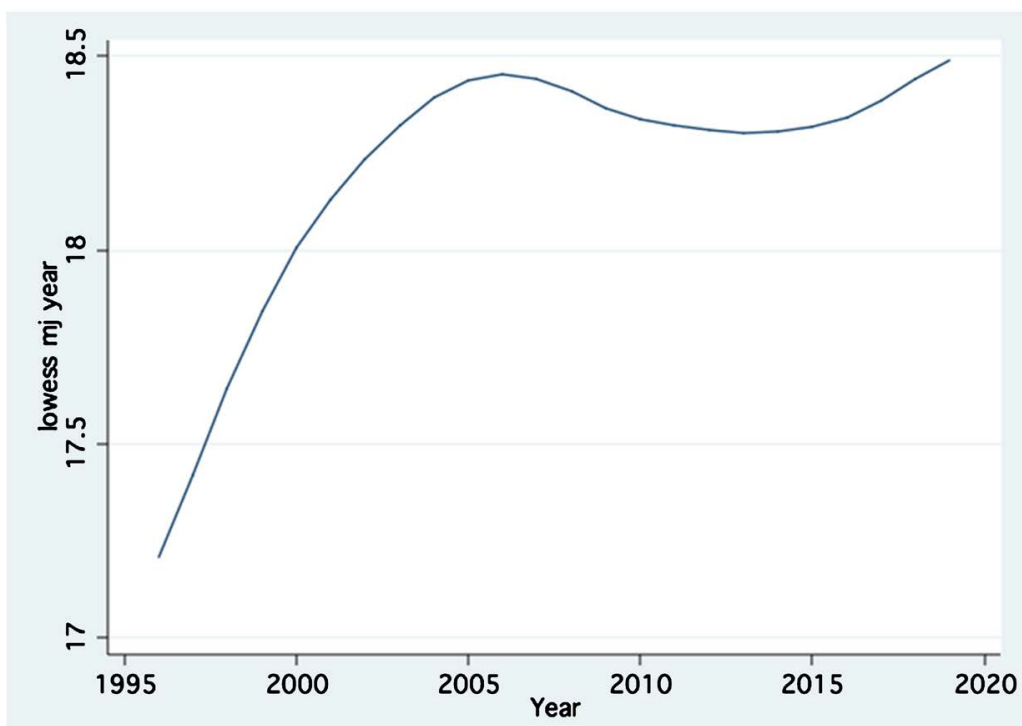

Figure 10. LOWESS (0.8) regression between time (months) and monthly (hourly data were averaged into daily and monthly means) record of radiation (MJ) measured in the meteorological station located in the central region of the Hula Valley during 2000-2019 (through July). 

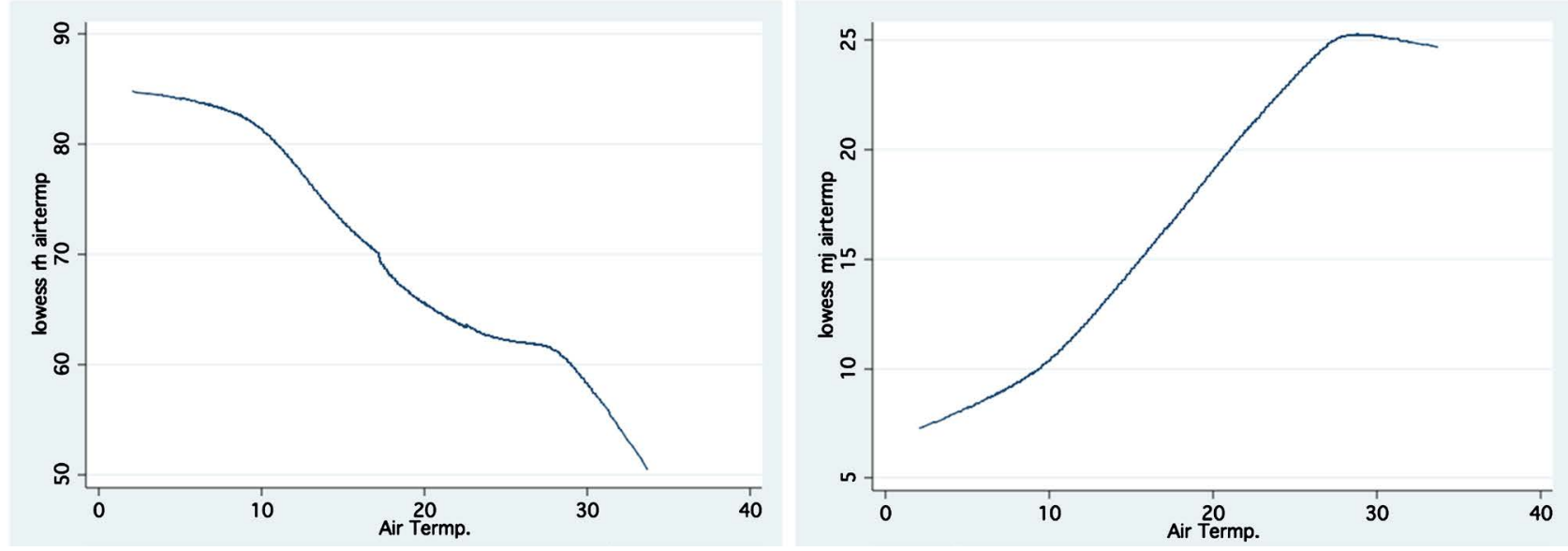

Figure 11. LOWESS (0.8) regression between daily (hourly data were averaged to daily and monthly means) record of air temperature (C) and relative humidity (\%) (left panel) and radiation (MJ) (right panel) measured in the meteorological station located in the central region of the Hula Valley during 2000-2019 (through July).

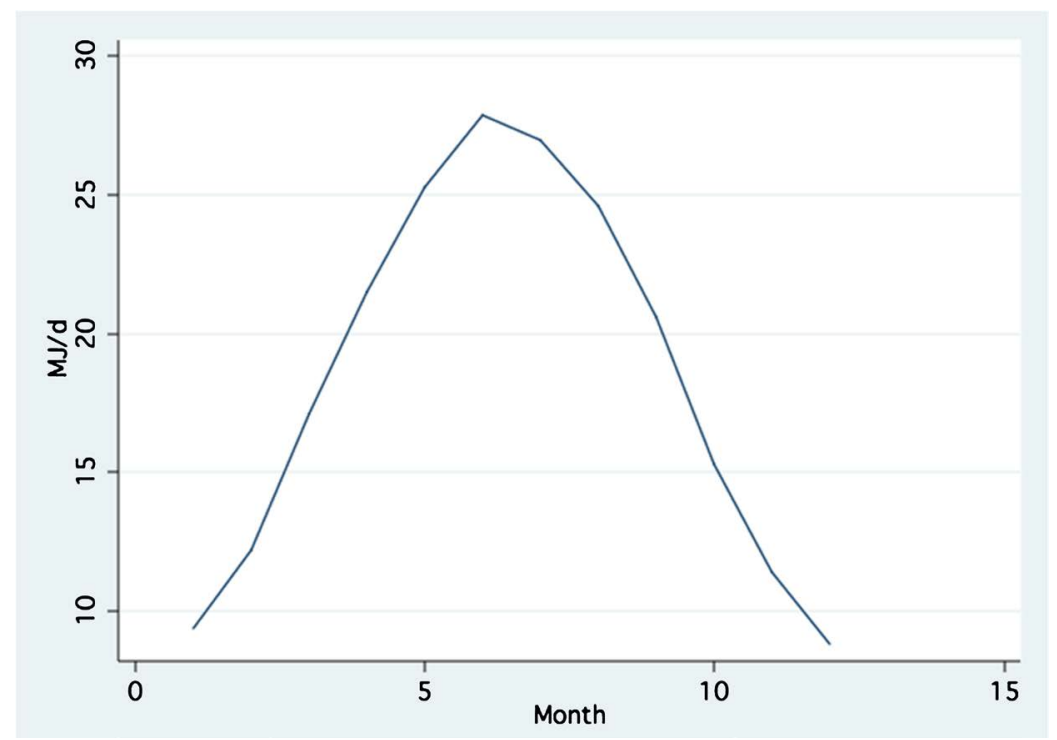

Figure 12. Line scatter plot of monthly means of radiation (MJ/d): hourly data were averaged to daily and monthly means. Radiation (MJ) measured in the meteorological station located in the central region of the Hula Valley during 2000-2019 (through July).

climatological parameters indicate the opposite [29] [30]: Figure 3, Figure 9, and 8-recent decline of rainfall, Figure 7, Figure 8, air temperature elevation, and in Figure 10 probably a slight increase of solar radiation. Moreover, plant transpiration rate and the hydrological symptoms as the outcomes of dryness process were widely studied. Those investigations are the basis for further Satellite images decoding. For instance, one acre of Corn (very common in the Hula Valley) transpire $11.4-15.1 \mathrm{~m}^{3}$ a day, and one big Oak tree $151 \mathrm{~m}^{3}$ per year. Thousands of Quercus (Oak) trees in The Yahudiye Park naturally consume approximately $(25-50) \times 10^{6} \mathrm{~m}^{3}$ of water every year and the distinct evaluation of such information from Landsat imaginary (Winn et al. 2019) is doubtful. The impact of climate conditions on plant physiology is well documented among 
many others by Wang et al. (2016). Their studies indicated that transpiration is then main driving force that reduces water during physiological drying and the main factors that influence this process are the air conditions. Therefore, we deny the rebuttal of recent Climate Change influence on water loss in the Kinneret drainage basin as claimed by Winn et al. (2019). Natural vegetation transpiration consumes part of the water rainfall contribution and air temperature elevation and solar radiation enhancement are of inducement for this consumption process. Moreover, rainfall decline not only lowered river discharges and Kinneret water inputs, but also enhanced creation of preferential free space in the Hula Peatland underground as an incentive for water loss.

The management of agriculture requires water consumption in the Hula Valley is not only significant as an income resource. It is also ultimately required for the peat soil deterioration prevention and Kinneret water protection. Removal of the agriculture from the Hula Valley will enhance soil structure deterioration, dust storms, underground fire and rodent outbreaks, and water loss. Consequently, part of the Kinneret water balance is dedicated to agricultural management in the Kinneret drainage basin and the partitioning allocation between farming and the lake water level demands is regulated efficiently by the National Water Authority.

\subsubsection{Chill Hours Record (1988-2019)}

We incorporated Chill hours results of the "Local Chill Hours" Model data collected during 1988-2019 as a supportive information service to grove crop managers. The computation of Chill hours is based on a modification of the "Chill Days Model" [31] [32] and the "Utah Model" as follows: Air Temperature $\left({ }^{\circ} \mathrm{C}\right)$ is continuously monitored and hourly averaged; each hour with mean temperature below $7^{\circ} \mathrm{C}$ is valued as 1 ; hourly temperature within average range of $7.0^{\circ} \mathrm{C}$ $10.0^{\circ} \mathrm{C}$ is valued as 0.5 ; mean range of $10.0^{\circ} \mathrm{C}-18.0^{\circ} \mathrm{C}$ is valued as 0 and higher than $18.0^{\circ} \mathrm{C}$ as -1 ; each 24 hours are totally summarized into one number: if the total summary is a positive number which is indicating the additional Chill hours for those 24 hours. Daily record of Chill Hours reflects obviously air temperature changes. Daily Chill Hours report is practically carried out during winter season (October through April). Long-term (1988-2019) record of daily Chill-Hours indicates annual atmospheric thermal fluctuations, i.e. climate change. Lake Kinneret and its watershed are located in a subtropical region and therefore hydrological seasonality is cycled from October through September of next year (Figure 13, Figure 14). The annual fluctuations of monthly means of air temperature are shown in Figure 14. The maxima, minima and averages clearly indicate decline during winter and elevation later on. Figures 15-17 indicates the following: temporal (1988-2019) decline of the daily number of chill hours (Figure 15); shortening length (in days) of the chill hours season (Figure 16) and the longer time delay (in days) of the initiation of chill hours existence (Figure 17). Conclusively, additional evidence of climate change occurrence which is represented as atmospheric air temperature elevation is given. 


\section{Conclusions and Recommendations}

Time series analysis of Standard Precipitation Index (SPI) values based on 87 years (1927-2014) of Annual Rainfall Record from Kfar Giladi Station (northern part of the Kinneret Drainage Basin) [27] has indicated 17 and 11 of negative indexes (higher level of aridity) during 1970-2014 and 1927-1970 periods respectively. That difference indicates recent climate change as higher level of aridity.

The disputed issue recently publicized includes two dissimilar conclusions:

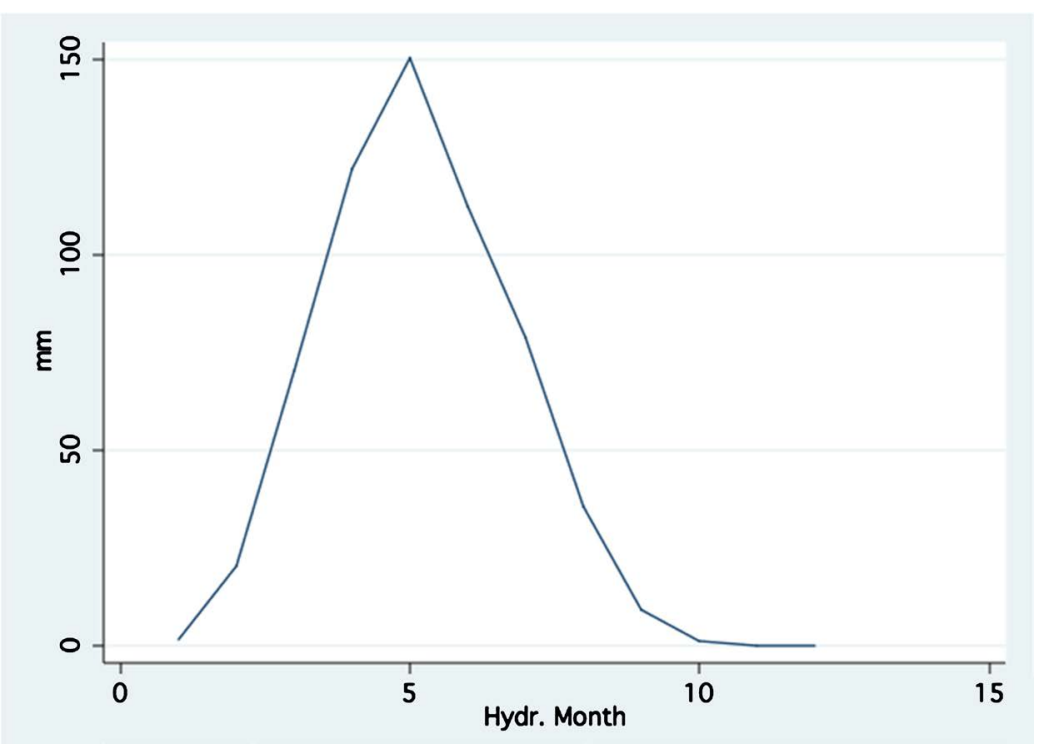

Figure 13. Line-scatter of multi-annual (40 years) averages of monthly precipitation gauge $(\mathrm{mm})$ of hydrological year: October $(=1)$ through next September $(=12)$ in Dafna Station.

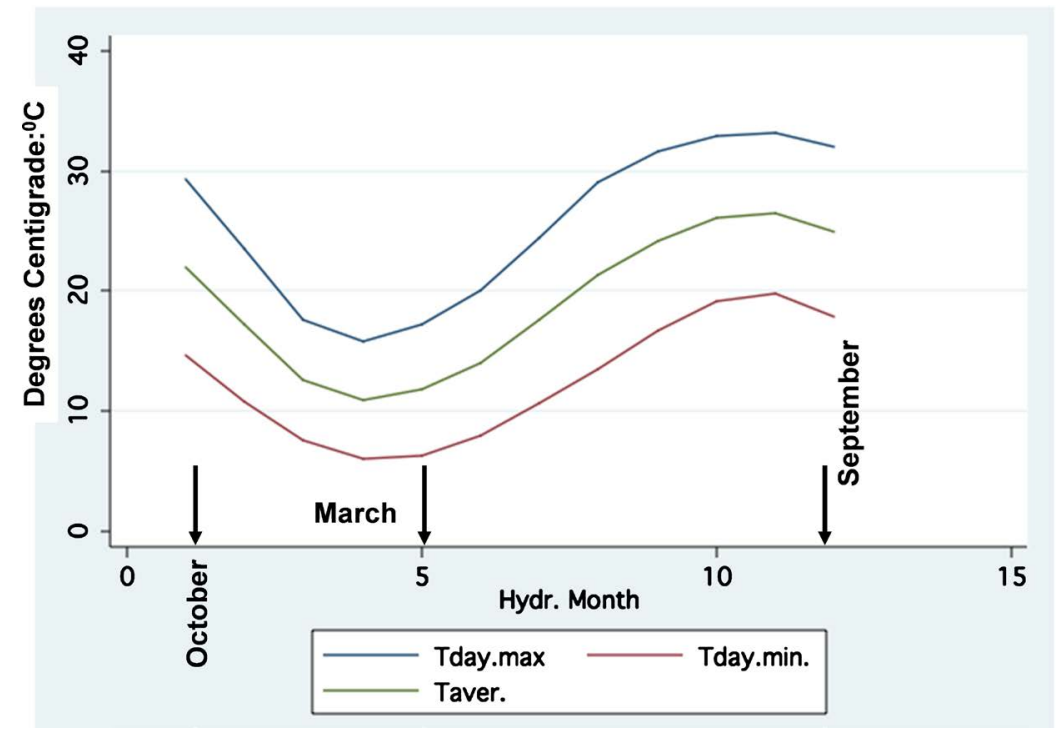

Figure 14. Line-scatter plot of multi-annual (40 years) averages of monthly means of maximum (upper) and minimum (lower) and mean (middle) (Max. + Min./2) daily air temperature vs. monthly plot of hydrological year: October $(=1)$ through next September (=12). 


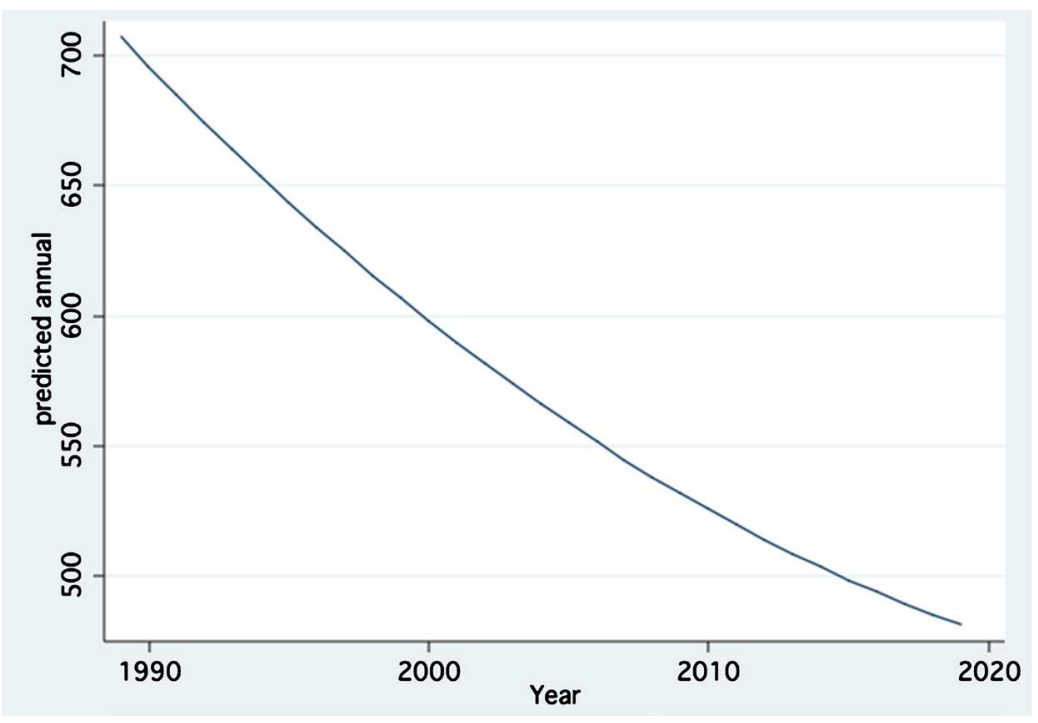

Figure 15. Total number of annual chill hrs vs years (1989-2019) (FP regression).

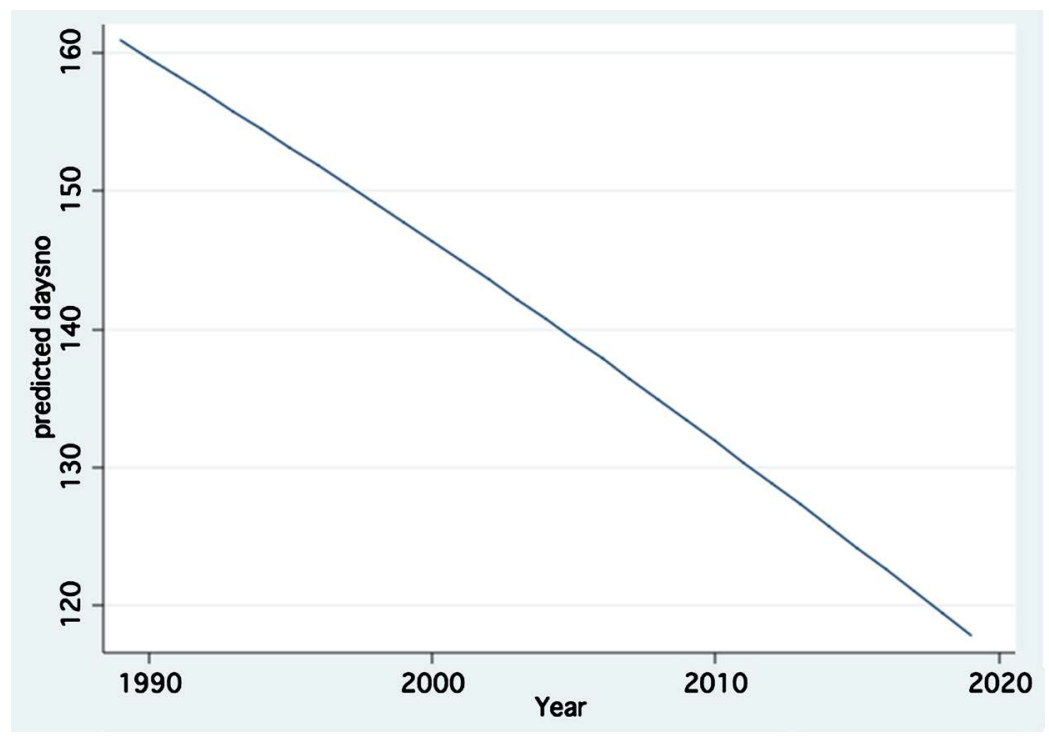

Figure 16. “Chill season” length (days) vs years (1989-2019) (FP regression).

Wine et al. (2019) and Wine (2019): Enhancement of Agricultural water consumption in the Upper Jordan Watershed caused a deficit in the Kinneret water balance and resulted in a WL decline; This paper and Tal (2019 a,b) indicate the misleading approach of it. Evaluation of the major components of the regional water balance indicates the following: Precipitation which is a natural input component whilst ET, underground flows and Runoff outputs are partly under anthropogenic control. Indications for climate change, i.e. warming trend of the atmosphere, are presented. Declining air temperature from 1940 until the late 1970s was then twisted into temperature elevation. The decline of air temperature between 1940-1980 is due to the change of Albedo factor. During the 1950s, old lake Hula and surrounding wetlands were drained and water cover surface was converted to plant cover, which enhanced sunlight energy reflection. 


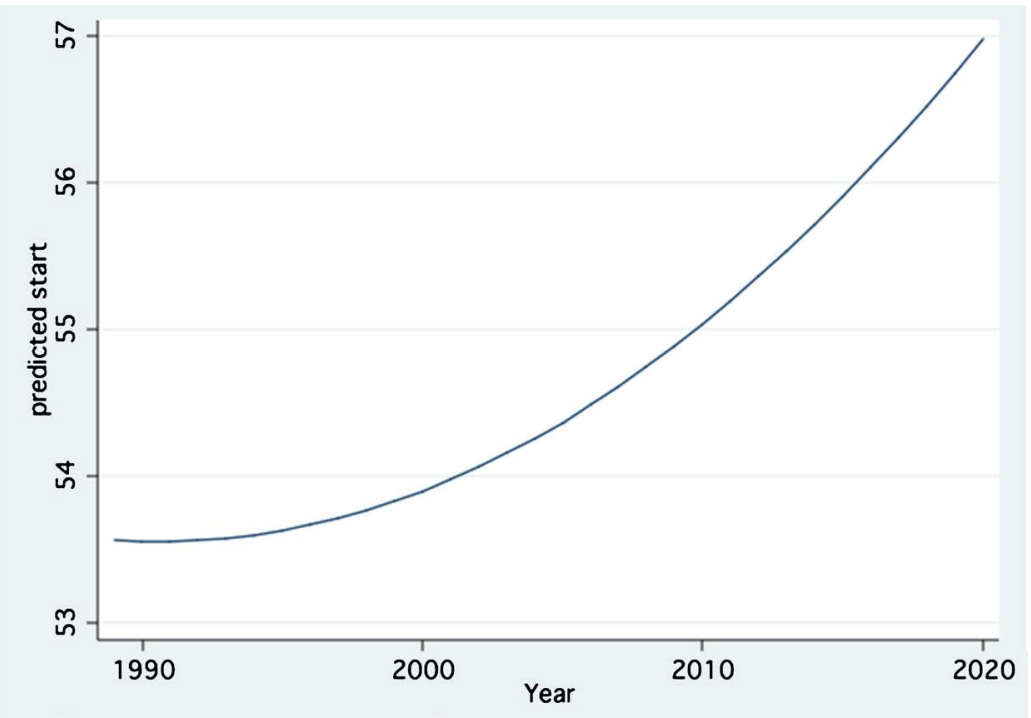

Figure 17. "Chill hrs" monitor starting time as number of days later than $1^{\text {st }}$ of October vs years (1989-2019) (FP regression).
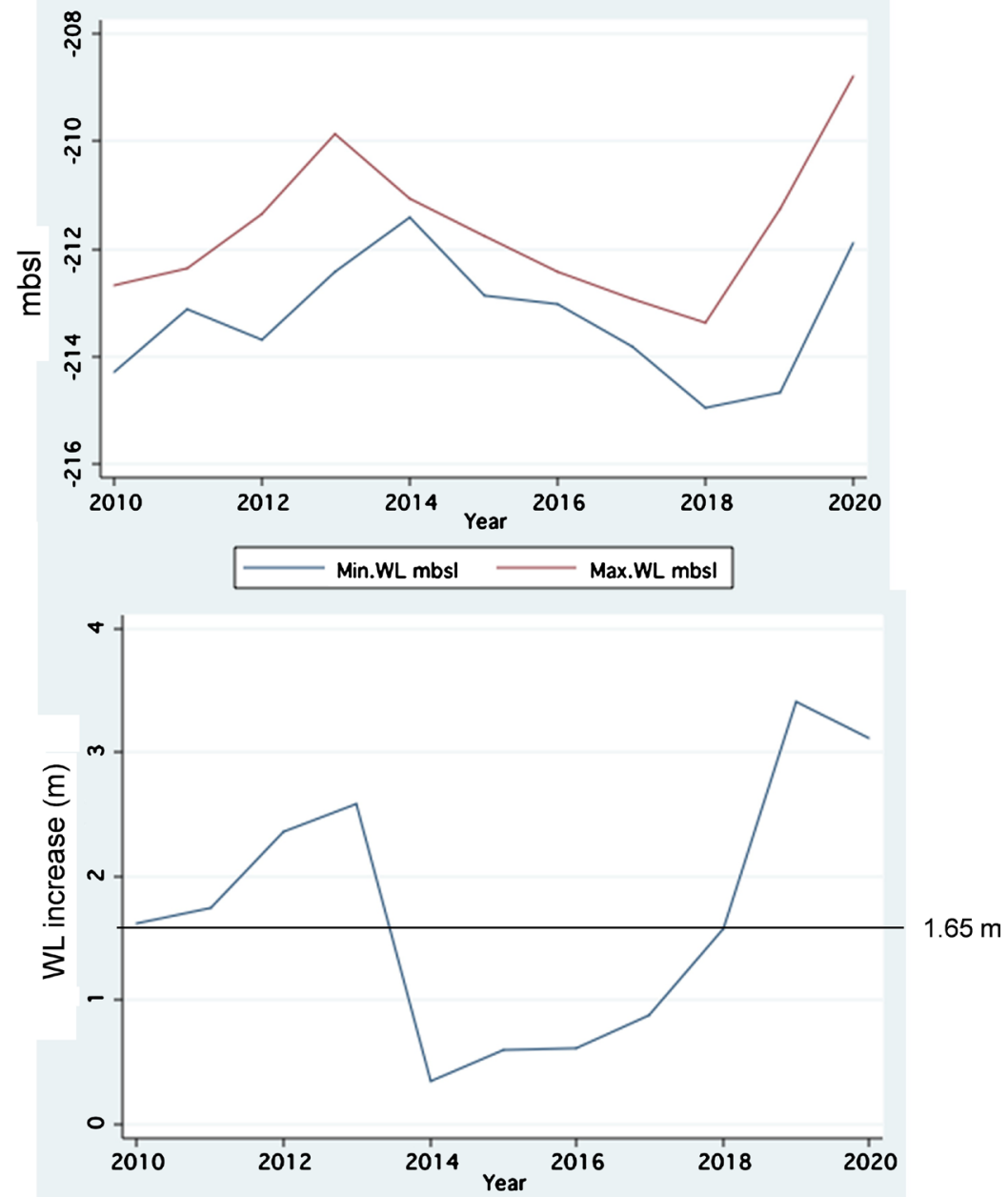

Figure 18. Annual changes of WL during 2010-2020: Upper Panel: highest (upper line) and lowest (lower line) annual WL (mbsl); Lower Panel: annual changes of WL increase (m). 
The other supportive parameters presented in this paper are: decline of rainfall, followed by a decline of Jordan and other rivers discharges and a consequent decline of Lake Kinneret WL. Climate change caused rainfall decline followed by a reduction of runoffs and consequently a decline of WL. Climate change towards dryness enhancement expressed as SPI, enhancement, precipitation decline, river discharges and lake input volumes decrease accompanied by lowered WL and water availability for supply and elongation of RT duration, increase of lake water salinity. Epilimnetic nitrogen deficiency and phosphorus sufficiency enhanced replacement of Peridinium by Cyanobacterial biomass. Nevertheless since 2010 lake water resource was replaced by desalinization water. Multi-annual (1933-2020) daily record of WL indicates an average annual increase of $1.65 \mathrm{~m}$ during winter time. Nevertheless exceptions of higher and/or lower of it are fairly common. These exceptions were critical for water supply regime during the period when Kinneret was the major source for domestic and agricultural national supply. These exceptions are also part of water deficiency for domestic and agricultural supply in the watershed northern to lake. Five hydrological cycles (October-September next year) 2013/2014-2017/2018 were a drought sequence in a row (Figure 18). The annual increase of the $\mathrm{WL}$ varied between 0.35 - $0.87 \mathrm{~m}$ during 2014-2017. After those five drought seasons, heavy rain winters came and WL elevation was 1.58, 3.41 and $3.10 \mathrm{~m}$ in 2018, 2019, 2020 respectively (the 2020 information includes documentation through March and later is predictable). The administrative consequence to droughts was a reduction of water allocation for agricultural irrigation, which resulted in a decline in the ET capacities.

\section{Conflicts of Interest}

The authors declare no conflicts of interest regarding the publication of this paper.

\section{References}

[1] Winn, M.L. (2019) There Is No Black Hole Swallowing Water in the Hula Valley. Land Use Policy, 84, 363-364. https://doi.org/10.1016/j.landusepol.2019.02.046

[2] Winn, M.L., Rimmer, A. and Laronne, J.B. (2019) Agriculture, Diversion, and Drought Shrinking Galilee Sea. Science of the Total Environment, 651, 70-83. https://doi.org/10.1016/j.scitotenv.2018.09.058

[3] Serruya, C. (1978) Chapter: Geography. In: Monographiae Biologicae, Vol. 32, Publisher Junk, Boston, New York, 7-13. https://doi.org/10.1007/978-94-009-9954-1_2

[4] Peri, D. (1967) General Characteristics of the Vegetation of the Hermon. Teva Vaaretz, 10, 4-8. (In Hebrew)

[5] Schumacher, G.C.E. (1888) The Jaulan; (“Across the Jordan”) Richard Bentley and Son. New Burlington Street; Translated (1976) by Permission, from the Transanction of the German Society, G'VIL Publishing House Jerusalem, 304 p.

[6] Zohary, M. (1955) Geobotany. Sifriyat Poalim Ltd., Maanit, 590 p. (In Hebrew)

[7] Kaplan, D. (2005) The Enigma of the Establishment of Quercus ithaborensis Park 
Forest in Northern Israel: Co-Evolution of Wild Boar and Men? Wildlife Biology in Practice, 1, 95-107. https://doi.org/10.2461/wbp.2005.1.12

[8] Kaplan, D. and Gutman, M. (1999) Phenology of Quercus ithaborensis with Emphasis on the Effect of Fire. Forest Ecology and Management, 115, 61-70. https://doi.org/10.1016/S0378-1127(98)00436-8

[9] Dolman, A.J., Verhagen, A. and Rover, C.A., Eds. (2003) Global Environmental Change and Land Use. Kluwer Academic Publishers, Dordrecht/Boston/London, 210 p. https://doi.org/10.1007/978-94-017-0335-2_1

[10] de Jong, B.H. (2000) Forestry for Mitigating the Greenhouse Effect: An Ecological and Economican Assessment of the Potential of Lad Use to Mitigate $\mathrm{CO}_{2}$ Emission in the High Land of Chiapas, Mexico. PhD Thesis, Wageningen University, Wageningen, The Netherlands.

[11] Henderson-Sellers, A. and Gornitz, V. (1984) Possible Climatic Impacts of Land Cover Transformations with Particular Emphasize on Tropical Deforestation. Climatic Changes, 6, 231-258. https://doi.org/10.1007/BF00142475

[12] Plantinga, A.J. and Mauldin, T. (2001) A Method for Estimating the Cost of $\mathrm{CO}_{2}$ Mitigation through Afforestation. Climate Change, 49, 21-40.

https://doi.org/10.1023/A:1010749214244

[13] Lean, J. and Rowntree, P. (1997) Understanding the Sensitivity of a GCM Simulation of Amazonian Deforestation to the Specification of Vegetation and Soil Characteristics. Journal of Climate, 10, 1216-1235. https://doi.org/10.1175/1520-0442(1997)010<1216:UTSOAG>2.0.CO;2

[14] Rabbinge, R., van Katesteijn, H.C. and Goudriaan, J. (1993) Assessing the Greenhouse Effect in Agriculture. In: Lake, J.V., Bock, G.R. and Ackrill, K. (Eds.), Environmental Change and Human Health, Ciba Foundation Symposium 175, John Wiley, Chichester, 62-79. https://doi.org/10.1002/9780470514436.ch5

[15] Nepstad, D.C., et al. (1994) The Role of Deep Roots in the Hydrological and Carbon Cycle of Amazon Forests and Pastures. Nature, 372, 666-669. https://doi.org/10.1038/372666a0

[16] Znovar Oved Gobi Ltd., Shacham, G.H., Tsaban, Y., Avnimelech and Ofer, A. (2011) Hula Project 2nd Stage, Development Program, Chapter: Opinion about Agricultural, Water Consumption, Environmental and Touristic Changes in the Hula Valley. Interim Report, 31 p. (In Hebrew)

[17] Gophen, M., Meron, M., Orlov-Levin, V. and Tsipris, Y. (2014) Seasonal and Spatial Distribution of N \& P substances in the Hula Valley (Israel) Subterranean. Open Journal of Modern Hydrology, 4, 121-131. https://doi.org/10.4236/ojmh.2014.44012

[18] Gophen, M. (2014) Land-Use, Albedo and Air Temperature Changes in the Hula Valley (Israel) during 1946-2008. Open Journal of Modern Hydrology, 4, 101-111. https://doi.org/10.4236/ojmh.2014.44010

[19] Gophen, M. (2019) Climate Change and Water Loss in the Kinneret Drainage Basin. Land Use Policy, 80, 424-429. https://doi.org/10.1016/j.landusepol.2018.03.008

[20] Wang, Z., Zhou, Z.X., Wang, X.M. and Chen, Z.J. (2017) Relationships between Transpiration Water Loss, and Air Conditions during Physiological Drying. Drying Technology, 36, 245-254. https://doi.org/10.1080/07373937.2017.1326499

[21] Reynard, N.S., Prudhomme, C. and Crooks, S.M. (2001) The Flood Characteristics of Large UK Rivers: Potential Effects of Changing Climate and Land Use. Climatic Change, 48, 343-359. https://doi.org/10.1023/A:1010735726818

[22] Howell, T.A. and Evert, S. (2004) The Penman-Monteith Method. 
https://www.researchgate.net/publication/241492864_The_Penman-Monteith_Met hod

[23] IMC (Israel Mapping Center) (1999) The National GIS Service, Editor: Information Systams Service, $22 \mathrm{p}$.

[24] Vossel, H., Roeser, P., Litt, T. and Reed, J.M. (2018) Lake Kinneret (Israel): New Insight into Holocene Regional Palaeoclimate Variability Based on High-Resolution Multi-Proxy Analysis. The Holocene, 28, 1395-1410. https://doi.org/10.1177/0959683618777071

[25] Hazan, D., Stein, M., Agnon, A., Marco, S., Nadel, D., Negendank, J.F.W., Schwabe, M. and Neev, D. (2005) The Late Quaternary Limnological History of Lake Kinneret (Sea of Galilee), Israel. Quaternary Research, 63, 60-77. https://doi.org/10.1016/j.yqres.2004.09.004

[26] Givati, A. and Rosenfeld, D. (2007) Possible Impacts of Anthropogenic Aerosols on Water Resources of the Jordan River and the Sea of Galilee. Water Resources Research, 43, W10419. https://doi.org/10.1029/2006WR005771

[27] Givati, A., Guillaume, T., Rosenfeld, D. and Paz, D. (2019) Climate Change Impacts on Streamflow at the Upper Jordan River Based on an Ensemble of Regional Climate Models. Journal of Hydrology: Regional Studies, 21, 92-109.

https://doi.org/10.1016/j.ejrh.2018.12.004

[28] Serruya, C. (1978) Chapter: Solar Radiation. In: Monographiae Biologicae, Vol. 32, Publisher Junk, Boston, New York, 59-62.

[29] Tal, A. (2019) Kinneret and Climate Change, Letting the Data Tell the Story. Science of the Total Environment, 685, 1272-1275. https://doi.org/10.1016/j.scitotenv.2019.05.282

[30] Tal, A. (2019) Letter to the Editor Regarding Wine et al. (2019): Lake Kinneret and Climate Change. Science of the Total Environment, 664, 175-176.

https://www.researchgate.net/publication/330967560 https://doi.org/10.1016/j.scitotenv.2019.01.371

[31] Byrne, D.H. and Bacon, T. (1992) Chilling Accumulation and Its Importance and Estimation. The Texas Horticulturist, 18, 8-9.

[32] Cesaraccio, C., Spano, D., Snyder, R.L. and Duce, P. (2004) Chilling and Forcing Model to Predict Bud-Burst of Crop and Forest Species. Agricultural and Forest Meteorology, 126, 1-13. https://www.sciencedirect.com https://doi.org/10.1016/j.agrformet.2004.03.002 